\title{
Korelasi Antara Lingkungan Belajar Dan Minat Belajar Siswa Dengan Hasil Belajar Matematika
}

\author{
N.P. Eka Arya Pratiwi ${ }^{*}$, I. M. Suarjana ${ }^{2}$, Ndara Tanggu Renda ${ }^{3}$ \\ ${ }^{123}$ PGSD, Fakultas Ilmu Pendidikan Universitas Pendidikan Ganesha Singaraja, Indonesia
}

\begin{abstract}
Abstrak
Penelitian ini bertujuan untuk mengetahui Korelasi Antara Lingkungan Belajar dengan hasil belajar Matematika Siswa, Korelasi antara Minat Belajar dengan hasil belajar matematika Siswa, dan Korelasi Antara Lingkungan Belajar dan Minat Belajar Siswa dengan Hasil Belajar Matematika Siswa. Jenis penilitian ini adalah penelitian Expost Fakto populasinya yaitu siswa SDN Gugus I Kecamatan Denpasar Timur Tahun

Keywords:

hasil belajar matematika, lingkungan belajar, minat belajar Pelajaran 2017/2018 yang berjumlah 146 siswa diambil sejumlah 97 sebagai sampel. Data diperoleh dengan penyebaran angket dan pencatatan dokumen. Data di analisis dengan korelasi product moment sederhana dan korelasi product moment berganda. Dengan teknik analisis statistik dekriptif dan inprensial yaitu Uji T. Dari hasil analisis

(1) Hasil analisis deskriptif menemukan bahwa lingkungan belajar berada pada kategori tinggi 46,39\%, Minat belajar berada pada kategori sangat tinggi 59,79\%, dan hasil belajar matematika berada pada katagori baik 95,88\%. (2) lingkungan belajar berhubungan nyata dan positif dengan hasil belajar matematika ditunjukkan karena t- hitung $(5,479)>t$ - tabel ( 1,667$)$. (3) minat belajar hubungan nyata dan positif dengan hasil belajar matematika ditunjukkan karena $\mathrm{t}$ - hitung $(6,625)>t$ - tabel $(1,667)$. (4) Ada hubungan positif antara lingkungan belajar, dan minat belajar dengan hasil belajar matematika dapat dilihat bahwa $r$ hitung 0,610 > r tabel 0,194 demikian juga hasil pengujian dengan uji f (secara simultan) dengan $\alpha=5 \%$ maka dapat diketahui bahwa lingkungan belajar, dan minat belajar secara serempak berhubungan signifikan dengan hasil belajar matematika.
\end{abstract}

\section{PENDAHULUAN}

Pendidikan merupakan salah satu bentuk dari hasil kebudayaan manusia yang dinamis dan selalu mengalami perkembangan. Oleh karena itu perubahan atau perkembangan pendidikan adalah hal yang memang sudah sewajarnya terjadi sejalan dengan perubahan budaya kehidupan manusia. Perubahan dalam hali ini adalah mengarah pada perbaikan pendidikan pada semua tingkat dan hal tersebut perlu terus menerus dilakukan sebagai antisipasi kepentingan di masa yang akan datang. Handayani (2015:iii), menegaskan salah satu hal yang tidak dapat dipisahkan dari pembelajaran matematika adalah Mathematical Habits of Mind. Kebiasaan berpikir matematis (Mathematical Habits of Mind) merupakan salah satu budaya yang penting untuk dikembangkan dalam lingkungan kelas ketika siswa mempelajari Matematika. Lingkungan belajar juga sangat mempengaruhi minat belajar siswa, lingkungan memberikan stimulus kepada siswa untuk berkonsentrasi, menumbuhkan motivasi ataupun menumbuhkan sikap dan daya bersaing dengan teman-teman sebayanya. Kondisi belajar mengajar yang efektif adalah adanya minat dan perhatian siswa dalam belajar. Minat belajar siswa sangat bergantung pada lingkungan belajar. Lingkungan belajar dalam konteks.

Dalam pembelajaran matematika pada khususnya. Kebanyakan orang menganggap bahwa matematika adalah tentang bidang hitung menghitung. Namun, ahli matematika memandang perhitungan hanyalah alat dalam matematika yang sesungguhnya, yang melibatkan pemecahan soal matematika dan

* Corresponding author. 
pemahaman struktur dan pola dalam matematika (National Research Council, 1999), Tujuan para guru untuk intruksi matematika mereka akan merefleksikan apa yang mereka anggap penting dalam matematika dan pendapat mereka tentang cara terbaik bagi murid untuk mempelajari matematika.Hal ini didukung oleh pendapat Susanto (2013: 158), yang menyatakan ada dua faktor yang mempengaruhi hasil belajar siswa yaitu faktor internal dan faktor eksternal. Faktor internal meliputi bakat, perhatian, dan kelelahan. Sedangkan faktor eksternal meliputi keluarga, sekolah dan masyarakat. Hal ini sejalan dengan yang dikatakan oleh Sudjana (1989: 39), bahwa hasil belajar yang dicapai oleh siswa dipengaruhi oleh dua faktor utama, yakno faktor dalam diri siswa dan faktor yang datang dari luar diri siswa atau faktor lingkungan. Faktor yang datang dari diri siswa terutama kemampuan yang dimilikinya. Faktor kemampuan siswa besar pengaruhnya terhadap hasil belajar siswa. Japa (2015) menyatakan pembelajaran matematika dimulai dari tingkat sekolah dasar (SD) adalah untuk membekali siswa berbagai kemampuan seperti: kemampuan berpikir logis, analitis, sistematis, kritis dan kreatif serta kemampuan bekerja sama. Lingkungan belajar adalah tempat berlangsungnya kegiatan belajar yang mendapatkan pengaruh dari luar terhadap kelangsungan kegiatan belajar. Lingkungan merupakan sumber belajar yang memiliki pengaruh dalam proses pembelajaran. Menurut Sanjaya (2010: 61), minat dapat diartikan sebagai suatu kesukaan, kegemaran atau kesenangan akan sesuatu. Adapun menurut Djiwandono (2002: 77), minat adalah suatu kondisi yang terjadi apabila seseorang melihat ciri-ciri atau arti sementara situasi yang dihubungkan dengan keinginan-keinginan atau kebutuhan-kebutuhan sendiri.

Berdasarkan permasalahan tersebut, maka dilakukan penelitian untuk mengetahui korelasi antara lingkungan belajar dan minat belajar di SD dengan melaksanakan penelitian yang berjudul " Korelasi antara lingkungan belajar dan minat belajar dengan hasil belajar matematika siswa kelas $\mathrm{V}$ semester genap SDN gugus I Kecamatan Denpasar timur tahun pelajaran 2017/2018". Penelitian ini memiliki tujuan (1) untuk mengetahui bagaimana hubungan antara lingkungan belajar dengan hasil belajar Matematika pada siswa kelas V di SDN Gugus I Kecamatan Denpasar Timur. (2) untuk mengetahui bagaimana hubungan antara minat belajar dengan hasil belajar Matematika pada siswa kelas V di SDN Gugus I Kecamatan Denpasar Timur. (3) untuk mengetahui bagaimana hubungan antara lingkungan belajar dan minat belajar dengan hasil belajar Matematika pada siswa kelas V di SDN Gugus I Kecamatan Denpasar Timur.

\section{METODE PENELITIAN}

Penelitian ini adalah jenis penelitian Expost Facto karena tidak dilakukan perlakuan (tratment) penelitian terhadap variabel-variabel penelitian. Penelitian ini juga menggunakan pendekatan kuantitatif, karena data dikumpulkan dalam bentuk angka dan bermaksud untuk menguji hipotesis tertentu (Koyan, 2010). Sesuai dengan permasalahan yang diteliti, rancangan penelitian ini termasuk jenis survei. Dantes (2012:36) menjelaskan penelitian survei pada umumnya dilakukan untuk mengambil generalisasi dari pengamatan yang tidak mendalam, namun generalisasi yang dilakukan bisa lebih akurat bila digunakan sampel yang representatif. Penelitian ini juga bersifat korelasi, karena berupaya untuk menjelaskan ada tidaknya hubungan antara variabel-variabel. Dalam penelitian ini di duga ada hubungan antara variabel bebas dengan variabel terikat. Prosedur yang ditempuh dilakukan dengan cara mengambil individu yang terdapat dalam masing-masing kategori populasi, sesuai dengan proporsi atau petimbangan untuk dijadikan sampel penelitian. Untuk menentukan jumlah sampel dalam penelitian ini digunakan tabel Isaac dan Michael, dengan tingkat kesalahan 1\%,5\%, dan 10\%.

Dalam penelitian ini tingkat kesalahan yang digunakan adalah $10 \%$. Berdasarkan penentuan jumlah sampel dari populasi 146 setelah dilihat pada tabel penentuan sampel subjek 146 berada pada $\mathrm{N}=150$ besar sampel 10\% adalah 97 (Agung,2014:71). Variabel pada penelitian ini adalah Lingkungan Belajar (X1), Minat Belajar (X2) dan Hasil Belajar Matematika (Y). Penelitian ini menggunakan dua teknik pengumpulan data, yaitu pencatatan dokumen, dan angket/kuisioner Sebelum angket disebar terlebih dahulu harus dilakukan uji coba, selanjutnya dilakukan pengujian validitas. Uji coba instrument bertujuan untuk mendapatkan gambaran secara empirik apakah instrument berupa angket atau kuisioner tersebut layak digunakan sebagai instrument penelitian yang baik. Berdasarkan hasil perhitungan uji validitas isi kuesioner lingkungan belajar di peroleh hasil sebesar 1,00 yang artinya bahwa validitas isi kuesioner lingkungan belajar berada pada kategori sangat tinggi dan hasil perhitungan uji validitas isi kuesioner lingkungan belajar di peroleh hasil sebesar 1,00 yang artinya bahwa validitas isi kuesioner minat belajar berada pada kategori sangat tinggi katakan kedua variabel yaitu lingkungan belajar dan minat belajar dinyatakan reliabel, karena uji reliabel lingkungan belajar 0,720 > r tabel 0,296 dan uji reliabel minat belajar 0,755 > $r$ tabel 0,296. Analisis statistik yang digunakan dalam penelitian ini ada dua yaitu analisis statistic deskriptif dan analisis regresi. Uji prasyarat analisis dalam penelitian ini ada empat yaitu uji normalitas, uji linieritas, uji multikolinieritas dan uji aoutokorelasi. Setelah uji prasayarat analisis terpenuhi baru dilanjutkan ke uji hipotesis dengan analisis regresi sederhana dan regresi ganda. 
Kemudian Uji T analisis koefisien regresi parsial ini digunakan untuk melakukan pengujian secara parsial antara variabel lingkungan belajar (x1) dan minat belajar (x2) dan dengan variabel hasil belajar matematika (y) beserta variabel lingkungan belajar (x1) dan minat belajar (x2) dengan pengujian masingmasing menggunakan uji-t. selanjutnya pengujian. Uji $\mathrm{F}$ bertujuan untuk menguji signifikan variabel bebas lingkungan belajar (x1), dan minat belajar (x2) secara serempak berhubungan terhadap hasil belajar matematika (y).

\section{ANALISIS DAN PEMBAHASAN}

Setelah analisis deskriptif dilakukan, didapatkan deskripsi data terkait lingkungan belajar, minat belajar dan hasil belajar matematika seperti pada Tabel 1 .

Tabel 1. Deskripsi Data Lingkungan Belajar, Minat Belajar Dan Hasil Belajar Matematika

\begin{tabular}{|c|c|c|c|}
\hline Valid & $\begin{array}{l}\text { Lingkungan Belajar } \\
97\end{array}$ & $\begin{array}{l}\text { Minat Belajar } \\
97\end{array}$ & $\begin{array}{l}\text { Hasil Belajar } \\
97\end{array}$ \\
\hline Mean & 94.57 & 81.18 & 79.63 \\
\hline Std. Deviation & 11.430 & 9.530 & 3.225 \\
\hline Varian & 11,430 & 90,813 & 10,402 \\
\hline Minimum & 61 & 55 & 72 \\
\hline Maximum & 113 & 99 & 86 \\
\hline
\end{tabular}

Tabel 1. Dari analisis kualifikasi lingkungan belajar yang berkatagori sangat tinggi sebanyak 33 orang $(34,02 \%)$, siswa yang berkatagori tinggi sebanyak 45 orang (46,39\%), siswa yang berkatagori sedang sebanyak 17 orang (17,52\%) dan siswa yang berkatagori rendah sebanyak 2 orang $(2,06 \%)$. Kualifikasi minat belajar siswa yang berkatagori sangat tinggi sebanyak 58 orang (59,79\%), siswa yang berkatagori tinggi sebanyak 32 orang (32,99\%) dan siswa yang berkatagori sedang sebanyak 7 orang (7,22\%). Sedangkan kualifikasi hasil belajar matematika siswa, sebanyak 4 orang siswa $(4,12 \%)$ berada pada kategori sangat baik dan sebanyak 93 orang siswa $(95,88 \%)$ berada pada kategori baik.

Uji hipotesis dalam penelitian ini adalah uji hipotesis dengan analisis regresi sederhana dengan menggunakan rumus korelasi product moment dengan berbantuan SPSS 22.0 For Windows (variable X1, dengan Y dan X2 dengan Y) serta analisis regresi ganda atau korelasi ganda (analisis bersama-sama anatara variable X1, X2 dengan Y) dalam pengujian hipotesis perlu adanya hipotesis alternative (Ha). untuk tujuan analisis data dirumuskan hipotesis nol (HO) karena dalam analisis statistika yang diuji adalah hipotesis nol (H0)

Sebelum melakukan uji hipotesis terlebih dahulu harus lulus uji prasyarat Sebelum melakukan uji hipotesis terlebih dahulu harus lulus uji prasyarat analisis yang pertama adalah uji normalitas. Adapun ringkasan uji normalitas dapat dilihat pada tabel 2

Tabel 2. Ringkasan Uji Normalitas

\begin{tabular}{lllllll}
\hline & \multicolumn{6}{l}{ Kolmogorov-smirnova $^{\text {S }}$} \\
\cline { 2 - 7 } & Statistic & Df & Sig. & Statistic & Df & Sig. \\
\hline Hasil belajar matematika & .087 & 97 & .082 & .983 & 97 & .111 \\
Lingkungan belajar & .073 & 97 & .090 & .977 & 97 & .032 \\
Minat belajar & .053 & 97 & .066 & .982 & 97 & .094 \\
\hline
\end{tabular}

Tabel 2. Hasil pengujian didapatkan bahwa data skor lingkungan belajar di dapat nilai kolmogorovsmirnov sebesar 0,090, selanjutnya data skor minat belajar di dapat nilai kolmogorov-smirnov sebesar 0,066, dan untuk data skor hasil belajar matematika di peroleh nilai kolmogorov-smirnov 0,082. Yang mana ketiga variabel pada kolom kolmogorov-smirnov $>0,05$, maka dapat disimpulkan bahwa data dari ketiga variabel yaitu lingkungan belajar, minat belajar dan hasil belajar matematika berdistribusi normal. 
belajar terhadap hasil belajar matematika siswa kelas V semester genap SDN Gugus I Kecamatan Denpasar Timur adalah di tolak, hal ini berarti hipotesis penelitian (ha) yang diajukan diterima. Dengan demikan ada hubungan yang signifikan antara lingkungan belajar dengan hasil belajar matematika matematika siswa kelas V semester genap SDN Gugus I Kecamatan Denpasar Timur. Kemudian pengujian hipotesis yang kedua antara variabel X2 yaitu minat belajar dengan variabel $\mathrm{Y}$ yaitu hasil belajar matematika di peroleh nilai uji signifikansi koefisien korelasi, diperoleh besarnya $r$ hitung $=0,609$ apabila kita konsultasikan dengan $r$ minat belajar dengan taraf signifikansi $5 \%$ dan $n=97$ maka dapat dilihat $r$ hitung $=0,609>r$ tabel 0,194 hasil perhitungan dan pengujiannya seperti pada tabel 6 di atas. Dengan demikian hipotesis 0 (ho) yang menyatakan tidak ada hubungan yang signifikan antara minat belajar dengan hasil belajar matematika siswa kelas V semester genap SDN Gugus I Kecamatan Denpasar Timur adalah di tolak, hal ini berarti hipotesis penelitian (ha) yang diajukan diterima. Dengan demikan ada hubungan yang signifikan antara minat belajar dengan hasil belajar matematika siswa kelas $\mathrm{V}$ semester genap SDN Gugus I Kecamatan Denpasar Timur. Selanjutnya pengujian dengan menggunakan Uji T koefisien regresi parsial ini digunakan untuk melakukan pengujian secara parsial antara variabel lingkungan belajar (x1) dan minat belajar (x2) dan dengan variabel hasil belajar matematika (y) beserta variabel lingkungan belajar (x1) dan minat belajar (x2) dengan pengujian masing-masing.

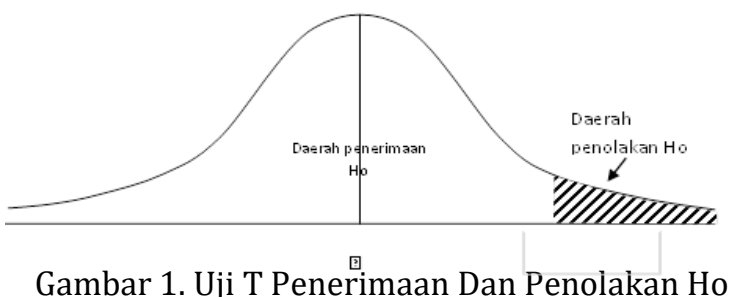

Oleh karena $\mathrm{t}$ - hitung $(5,479)>t$ - tabel $(1,667)$, maka h0 ditolak berarti secara statistik ada hubungan nyata dan positif antara lingkungan belajar (x1) terhadap hasil belajar matematika (y). Dari hasil regresi ini juga dapat di interprestasikan bahwa ada hubungan yang nyata antara lingkungan belajar (x1) terhadap hasil belajar matematika (y). Hal ini diperkuat dengan nilai signifikansi 0,00 yang lebih kecil dari 0,05.

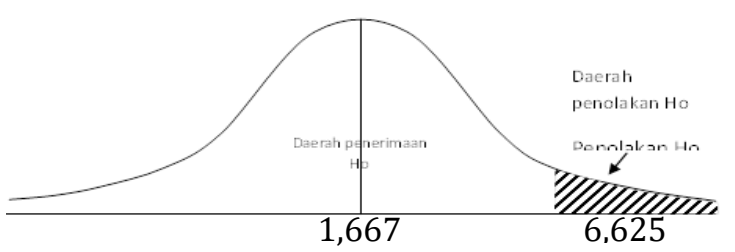

Gambar 2. Uji T Penerimaan Dan Penolakan Ho

Oleh karena $\mathrm{t}$ - hitung $(6,625)>\mathrm{t}$ - tabel $(1,667)$, maka h0 ditolak berarti secara statistik ada hubungan nyata dan positif antara minat belajar (x2) dengan hasil belajar matematika (y). Dari hasil regresi ini juga dapat di interprestasikan bahwa ada hubungan yang nyata antara minat belajar (x2) dengan hasil belajar matematika (y). Hal ini diperkuat dengan nilai signifikansi 0,00 yang lebih kecil dari 0,05. Selanjutnya menggunakan uji F, Pengujian ini bertujuan untuk menguji signifikan variabel bebas lingkungan belajar (x1), dan minat belajar (x2) secara serempak berhubungan terhadap hasil belajar matematika $(\mathrm{y})$.

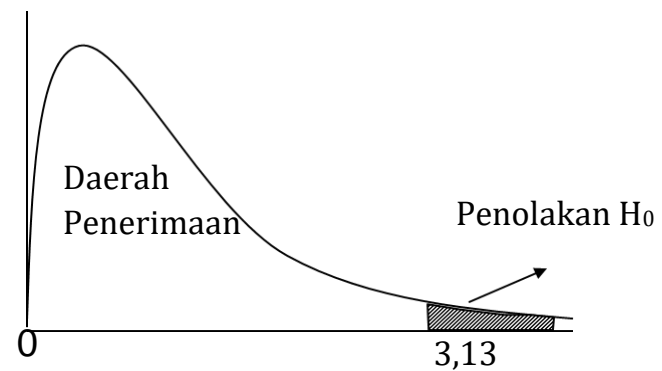

Gambar 3. Uji F Penerimaan Dan Penolakan Ho 
Oleh karena f hitung $>$ f tabel yaitu 20,183 > 3,13 atau statistik uji jatuh pada daerah penolakan h0 maka h0 ditolak dan h1 diterima. Hal ini berarti variabel bebas yang terdiri dari lingkungan belajar (x1), minat belajar (x2) secara serempak berhubungan signifikan dengan hasil belajar matematika (y). Hal ini juga diperkuat dengan tingkat signifikansi 0,000 yang lebih kecil dari 0,05.

Pembahasan hasil penelitian hasil deskriptif tentang lingkungan belajar, minat belajar, dan hasil belajar matematika di temukan bahwa lingkungan belajar berada pada kategori tinggi dengan besarnya persentase sebesar 46,39\%, minat belajar berada pada kategori sangat tinggi dengan besarnya persentase sebesar 59,79\%, dan hasil belajar matematika siswa kelas V di SDN Gugus I Kecamatan Denpasar Timur Tahun Pelajaran 2017/2018 berada pada kategori sangat baik dengan presentase $95,88 \%$

Berdasarkan hasil analisis data yang menggunakan produk moment dan Uji T yang di tunjukkan pada gambar 1 dan tabel 6 uji T, Penelitian ini ditemukan bahwa ada hubungan nyata dan positif antara lingkungan belajar (x1) dengan hasil belajar matematika (y). Ini ditunjukkan karena r-hitung $(0,504)>$ dari r-tabel $5 \%=(0,194)$ adalah signifikan, demikian juga $t-$ hitung $(5,479)>t-\operatorname{tabel}(1,667)$. Dari hasil regresi ini juga dapat di interprestasikan bahwa ada hubungan yang nyata antara lingkungan belajar (x1) dengan hasil belajar matematika (y) siswa kelas V di SDN Gugus I Kecamatan Denpasar Timur Tahun Pelajaran 2017/2018. Hal ini diperkuat dengan nilai signifikansi 0,00 yang lebih kecil dari 0,05 dengan besarnya hubungan sebesar 25,4 persen. Ini artinya bahwa ada sebesar 74,6 persen ada hubungan faktor lain yang mempunyai hubungan dengan hasil belajar matematika siswa kelas V di SDN Gugus I Kecamatan Denpasar Timur Tahun Pelajaran 2017/2018.

Menurut Prayitno menguraikan indikator lingkungan sekolah adalah (a) Hubungan antara guru dengan siswa, (b) Hubungan antara siswa dengan siswa lain, (c) Alat belajar, (d) Kurikulum, (e) Displin sekolah, dan (f) Kondisi gedung. Akan berdampak terhadap hasil belajar, Apabila lingkungan belajar semakin positif terhadap hasil belajar matematika maka semakin tinggi pula hasil belajar yang dapat di raih oleh peserta didik. Begitu pula sebaliknya apabila lingkungan belajar negative terhadap hasil belajar maka akan semakin rendah prestasi yang di raih oleh peserta didik. Apabila dalam lingkungan keluarga tercipta suasana yang harmonis, keinginan untuk belajar akan lebih termitivasi. Dapat menimbulkan rasa senang dan nyaman untuk belajar. Di lingkungan sekolah, apabila memiliki keakraban dengan teman yang memiliki sifat suka belajar dapat meningkatkan keinginan untuk belajar lebih giat lagi. Dalam penelitian ini, tingkat hubungan lingkungan belajar dengan hasil belajar matematika tergolong cukup baik. Hal ini sejalan dengan temuan penelitian yang dilakukan oleh Maryati, dkk (dalam jurnal mimbar PGSD Vol. 2 No:1), hubungan antara lingkungan belajar dan minat belajar dengan hasil belajar matematika terdapat hubungan yang signifikan antara lingkungan belajar dengan hasil belajar Matematika dengan koefisiensi korelasi sebesar 0,684.

Demikian juga berdasarkan hasil analisis data product moment dan uji T pada gambar 2 dan tabel 6 uji T. Penelitian ini ditemukan bahwa ada hubungan nyata dan positif antara minat belajar (x2) dengan hasil belajar matematika (y) siswa kelas V di SDN Gugus I Kecamatan Denpasar Timur Tahun Pelajaran 2017/2018. Ini ditunjukkan karena r-hitung $(0,609)>$ dari r-tabel $5 \%=(0,194)$ adalah signifikan, demikian juga $\mathrm{t}$ - hitung $(6,625)>\mathrm{t}-$ tabel $(1,667)$. Dari hasil regresi ini juga dapat di interprestasikan bahwa ada hubungan yang nyata antara minat belajar (x2) dengan hasil belajar matematika (y) siswa kelas V di SDN Gugus I Kecamatan Denpasar Timur Tahun Pelajaran 2017/2018. Hal ini diperkuat dengan nilai signifikansi 0,00 yang lebih kecil dari 0,05 dengan besarnya hubungan sebesar 37,1 persen. Ini artinya bahwa ada sebesar 62,9 persen ada hubungan faktor lain yang mempunyai hubungan dengan hasil belajar matematika siswa kelas V di SDN Gugus I Kecamatan Denpasar Timur Tahun Pelajaran $2017 / 2018$.

Minat belajar siswa erat hubungannya dengan kepribadian, motivasi, ekspresi, dan konsep diri atau identifikasi, faktor keturunan, dan pengaruh eksternal atau lingkungan. sebagai suatu ketertarikan terhadap suatu objek yang kemudian mendorong individu untuk mempelajari dan menekuni segala hal yang berkaitan dengan minatnya tersebut. Sardirman (2007:19) yang menyatakan, timbulnya minat pada diri seseorang pada prinsipnya dapat dibedakan menjadi dua jenis, yaitu: Pertama, minat yang berasal dari pembawaan, timbul dengan sendirinya dari setiap individu, hal ini biasanya dipengaruhi oleh faktor keturunan atau bakat alamiah. Kedua, minat yang timbul karena adanya pengaruh dari luar diri individu, timbul seiring dengan proses perkembangan individu bersangkutan. Bloom juga menunjukkan bahwa prestasi dan subject-related affect saling berhubungan dan saling mempengaruhi. Prestasi yang tinggi meningkatkan afek positif, dimana afek yang positif ini membuat prestasi menjadi tinggi dan prestasi yang lebih tinggi ini juga membuat afek semakin positif. Demikian sebaliknya, prestasi yang rendah menurunkan afek positif, yang menekan prestasi selanjutnya dan ini lebih lanjut menurunkan lagi afek positif. Dalam penelitian ini, tingkat hubungan minat belajar dengan hasil belajar matematika tergolong cukup baik. 
Hasil penelitian ini sejalan dengan penelitian yang dilakukan oleh Ermelinda, Benge (dalam Journal of Education Technology Vol.1 No:4), hubungan antara minat dengan hasil belajar ipa pada siswa sd menyimpulkan bahwa: (1) terdapat hubungan yang positif dan signifikan antara minat belajar dengan hasil belajar IPA pada siswa kelas V SDI Bajawa melalui persamaan regresi $\hat{Y}=17.335+0,040$ X1 dengan kontribusi sebesar 0,8 \% dan sumbangan efektifnya sebesar 0,01\%, Dengan analisis korelasi ganda dan uji $\mathrm{f}$ pada gambar 3 di temukan bahwa ada hubungan antara lingkungan belajar (x1), dan minat belajar (x2) dengan hasil belajar matematika siswa kelas V di SDN Gugus I Kecamatan Denpasar Timur Tahun Pelajaran 2017/2018, hal ini dapat dilihat bahwa $r$ hitung 0,610 > r tabel 0,194 demikian juga berdasarkan hasil pengujian dengan uji f (secara simultan) dengan $\alpha=5 \%$ maka dapat diketahui bahwa lingkungan belajar ( $x 1$ ), dan minat belajar (x2) secara serempak berhubungan signifikan terhadap hasil belajar matematika (y) siswa kelas V di SDN Gugus I Kecamatan Denpasar Timur Tahun Pelajaran 2017/2018. Oleh karena f hitung > f tabel yaitu 20,183 > 3,13 atau statistik uji jatuh pada daerah penolakan h0 maka h0 ditolak dan hi diterima. Hal ini juga diperkuat dengan tingkat signifikansi 0,00 yang lebih kecil dari 0,05 dengan besarnya hubungan sebesar 37,2 persen. Ini artinya bahwa ada sebesar 62,8 persen ada hubungan faktor lain yang mempunyai hubungan dengan hasil belajar matematika siswa kelas V di SDN Gugus I Kecamatan Denpasar Timur Tahun Pelajaran 2017/2018.

\section{KESIMPULAN}

Berdasarkan hasil penelitian dan analisis data statistik, maka dapat disimpulkan sebagai berikut (1) Hasil analisis deskriptif menemukan bahwa lingkungan belajar berada pada kategori tinggi dengan besarnya persentase sebesar 46,39\%, minat belajar berada pada kategori sangat tinggi dengan besarnya persentase sebesar 59,79\%, dan hasil belajar matematika berada pada katagori baik dengan presentase 95,88\%. (2) Penelitian ini menemukan bahwa ada hubungan nyata dan positif antara lingkungan belajar (x1) dengan hasil belajar matematika (y). Ini ditunjukkan karena r-hitung $(0,504)>$ dari r-tabel $5 \%=($ $0,194)$ adalah signifikan, demikian juga $t-$ hitung $(5,479)>t-\operatorname{tabel}(1,667)$. Dari hasil regresi ini juga dapat di interprestasikan bahwa ada hubungan yang nyata antara lingkungan belajar (x1) dengan hasil belajar matematika (y). Hal ini diperkuat dengan nilai signifikansi 0,00 yang lebih kecil dari 0,05 dengan besarnya hubungan sebesar 25,4 persen. Ini artinya bahwa ada sebesar 74,6 persen ada hubungan faktor lain yang mempunyai hubungan dengan hasil belajar matematika.(3) Penelitian ini menemukan bahwa ada hubungan nyata dan positif antara minat belajar (x2) dengan hasil belajar matematika (y). Ini ditunjukkan karena r-hitung $(0,609)>$ dari $r$-tabel $5 \%=(0,194)$ adalah signifikan, demikian juga $t-$ hitung $(6,625)>t-$ tabel $(1,667)$. Dari hasil regresi ini juga dapat di interprestasikan bahwa ada hubungan yang nyata antara minat belajar (x2) dengan hasil belajar matematika (y). Hal ini diperkuat dengan nilai signifikansi 0,00 yang lebih kecil dari 0,05 dengan besarnya hubungan sebesar 37,1 persen. Ini artinya bahwa ada sebesar 62,9 persen ada hubungan faktor lain yang mempunyai hubungan dengan hasil belajar matematika. (4) Secara simultan ditemukan bahwa ada antara lingkungan belajar (x1), dan minat belajar (x2) dengan hasil belajar matematika, hal ini dapat dilihat bahwa $r$ hitung 0,610>r tabel 0,194 demikian juga berdasarkan hasil pengujian dengan uji $\mathrm{f}$ (secara simultan) dengan $\alpha=5 \%$ maka dapat diketahui bahwa lingkungan belajar ( $\mathrm{x} 1$ ), dan minat belajar ( $\mathrm{x} 2$ ) secara serempak berhubungan signifikan terhadap hasil belajar matematika (y). Oleh karena f hitung $>\mathrm{f}$ tabel yaitu 20,183 > 3,13 atau statistik uji jatuh pada daerah penolakan h0 maka h0 ditolak dan hi diterima. Hal ini juga

diperkuat dengan tingkat signifikansi 0,00 yang lebih kecil dari 0,05 dengan besarnya hubungan sebesar 37,2 persen. Ini artinya bahwa ada sebesar 62,8 persen ada hubungan faktor lain yang mempunyai hubungan dengan hasil belajar matematika.

Adapun saran yang dapat disampaikan, berdasarkan hasil penelitian ini sebagai berikut. (1) Bagi siswa, siswa hendaknya selalu berusaha belajar secara lebih teratur sehingga dapat meningkatkan hasil belajar matematika. (2) Bagi sekolah, dari hasil penelitian ditemukan bahwa variabel Lingkungan Belajar, dan Minat Belajar berHubungan signifikan terhadap Hasil belajar matematika Kelas V SD di Gugus I Kecamatan Denpasar Timur, oleh karena itu disarankan kepada kepala sekolah dan guru matemnatika siswa V SD di Gugus I Kecamatan Denpasar Timur bahwa dalam upaya mengatasi permasalahan tentang hasil belajar matematika agar lebih meningkat supaya mencermati pada aspek lingkungan belajar, minat belajar yang telah ada dan telah dilaksanakan Kelas V SD di Gugus I Kecamatan Denpasar Timur agar lebih ditingkatkan lagi.(3) Bagi guru, minat belajar yang dilakukan di kelas V SD di Gugus I Kecamatan Denpasar Timur lebih dominan berhubungan dengan hasil Belajar matematika, untuk itu disarankan bahwa minat belajar yang telah dilaksanakan dapat dipertahankan dan ditingkatkan.(4) Bagi peneliti atau calon peneliti yang tertarik dengan masalah ini, dapat melakukan penelitian yang lebih mendalam tentang factor - faktor yang berhubungan dengan hasil belajar matematika lainnya motivasi belajar, kemandirian belajar, dan tingkat perhatian orang tua. 


\section{DAFTAR PUSTAKA}

Alexander, D.J. 2000. Newcastle Disease and other Avian Paramyxovirus. Rev. sci. tech. Off. int. Epiz. Vol. 19, No. 2, Hal. 443-462. Central Veterinary Laboratory, Weybridge, New Haw, Addlestone, Surrey KT15 3NB, United Kingdom

Ames, C \& Archer, J. 1998.Achievement goals in the classroom: Students' learning strategies and motivation processes. Journal of Educational Psychology. Vol. 80, no. 3, 260-267. The American psychological Assiciation, Inc . www.digilib.uinsby.ac.id.Maret 2017.

Agung, Anak agung Gede. 2014. Metedologi Penelitian Pendidikan. Singaraja, Aditya Media Publishing.

Astuni, Rai, dkk. (2013). "Pengaruh Strategi React Berbantuan Lingkungan Sebagai Sumber Belajar Terhadap Hasil Belajar IPA Kelas V Di Gugus Xiii Kecamatan Buleleng”. e-journal Mimbar PGSD Universitas Pendidikan Ganesha, Jurusan PGSD Vol.1 No: 1.

Apsari Decy Anden, I Dewa Ayu, dkk. (2013). “Korelasi Minat Belajar Matematika Dan Lingkungan Belajar Terhadap Prestasi Belajar TIK”. e-journal Mimbar FTK Universitas Pendidikan Ganesha, Jurusan Teknik Informatika Vol.2 No: 5.

Benge, Ermelinda. (2017). "Hubungan Antara Minat Dan Motivasi Belajar Dengan Hasil Belajar IPA Pada Siswa SD”. e-journal Mimbar Journal of Education Technology. Vol. 1 No: 4.

Dantes, Nyoman. 2012. Metode Penelitian. Yogyakarta: C V Andi Offset.

Dipayana, I. D. (2014). "Pengaruh Strategi Pembelajaran Rotating Trio Exchange (Rte) Terhadap Hasil Belajar Matematika”. e-journal Mimbar PGSD Universitas Pendidikan Ganesha, 2(1).

Djiwandono, Sri Esti Wuryani. 2002. Psikologi Pendidikan. Jakarta: PT Grasindo

Handayani, Dwi Aprilia. (2015). "Mathematical Habits Of Mind: Urgensi Dan Penerapannya Dalam Pembelajaran Matematika. e-journal Mimbar Pendidikan Matematika Universitas Nusantara PGRI Kediri" Vol. 1 No 2 Tahun 2015.

Japa Ngurah, I Gusti dan I Made Suarjana. 2015. Pendidikan Matematika I. Singarja: Universitas Pendidikan Ganesha.

Juli Wiriasa, I Gusti Putu, dkk. (2017). Pengaruh Implementasi Teknik Team Quiz Terhadap Hasil Belajar Ipa Ditinjau Dari Sikap Ilmiah Siswa Kelas Vi Sd Gugus I Kecamatan Kuta Selatan”. e-journal Mimbar PGSD Universitas Pendidikan Ganesha, Program Pascasarjana Vol.7 No: 1.

Koyan, I Wayan. 2012. Statistik pendidikan Teknik analisis Data Kuantitatif. Singaraja: Universitas Pendidikan Ganesha.

Maryati, dkk.(2015). "Hubungan Antara Lingkungan Dan Minat Belajar Dengan Hasil Belajar Matematika Siswa Kecamatan Rajabasa Kota Bandar Lampung”. e-journal Mimbar PGSD Universitas Pendidikan Ganesha, Jurusan PGSD Vol. 2 No: 1.

Mulyasa. 2008. Menjadi Guru Profesional. Bandung: PT Remaja Rosdakarya

Polih, Sri, dkk. (2014). "Pengaruh Model Pembelajaran Learning Cycle Berbasis Media Lingkungan Alam Terhadap Hasil Belajar IPA Siswa Kelas V SDN 5 Pedungan Denpasar”. e-journal Mimbar PGSD Universitas Pendidikan Ganesha, Jurusan PGSD Vol.1 No: 1.

Prayitno. 2011. Dasar Teori dan Praksis Pendidikan. Jakarta: PT Gramedia Widiasarana Indonesia.

Sanjaya, Wina. 2010. Kurikulum dan pembelajaran. Jakarta: Kencana Edisi III

Sardirman, 2007. Interaksi dan Motivasi Belajar mengajar. Jakarta: PT RajaGrafinda Persada

Susanto, Ahmad. 2013. Teori Belajar dan pembelajaran di Sekolah Dasar. Jakarta: Prenadamedia Group 